\title{
Creating and Innovating English Language Teaching by Developing Cultural Model for Literacy
}

\author{
Rita Inderawati \\ Faculty of Teachers Training and Education \\ Sriwijaya University \\ Palembang, Indonesia \\ ritarudisaid@yahoo.com
}

\author{
Sofendi \\ Faculty of Teachers Training and Education \\ Sriwijaya University \\ Palembang, Indonesia \\ Sofendi@yahoo.com
}

- Abstract-Literary works are valuable for the enhancement of students' competence of language as many experts consider that no black box could be found in language and literature. This current article highlights three essential things explored through Research and Development study, as follows: (1) to implement a teaching pattern based on reader response strategy (RRS) and visual symbols responses through Facebook, (2) to transliterate the dimension of visual symbol responses in English Language Teaching, and (3) to identify Cultural Model for Literacy (CML) integrated in all levels of education. The samples of the study were the fifth-semester students of English Education Study Program of Education Faculty Sriwijaya University in the academic year 2014/2015 who took Literary Appreciation and SPEAKING II course, state junior, and senior high school students. Data were collected by observing, testing, and distributing questionnaire. The research results showed that CML could be implemented fully and partially based on the focus of the literacy built by collaborating reader response strategy and visual symbol responses and utilizing technology. The results of this study could be implemented in schools and other language educations.

Keywords- CML, ELT, RRS, visual symbol responses, Facebook

\section{INTRODUCTION}

The ability to read a sign or symbol indicates the literate person to reach an understanding of high literacy. In relation to the Literary Appreciation course, the sign is a response to visual symbols that are the four visual dimensions: graphs, illustrations, film/video, and performance art [1] . The visual symbol responses have been used in teaching that course since 2006. Ref [2] defines a visual symbol as representative of the immediate reality that came in the form of signs or symbols. In their study, ref [3] found that learning theoretically and well organized is very useful to guide teachers teach and create a comfortable learning atmosphere that combines the development of literacy with curriculum learning in all contexts.
Ref [4] reported the results of her research by collaborating reader response and visual symbols in teaching literature to improve the writing skill of elementary school students. Such efforts indicate that one of the students' language skills can be improved. In other studies, ref [5] found that students can improve their speaking and writing skills by facilitating visual symbols as suggested by [1], "... one of the tasks of English teachers is to help students communicate effectively their responses in both writing and speaking." As for Taufik Ismail with poetry house, [6] in the realm of Competence Grant Year II DP2M Higher Education established the Forum Literature for All at FKIP Sriwijaya University as one of the outcomes of research. The establishment of the forum was based on the results of a questionnaire distributed to the students, English lecturers, and junior high school teachers. The activity in the forum was to read and to appreciate literature, as well as creating a performance art aimed not only at the language students but also the entire faculties at Sriwijaya University. The studies - did by [6] who realized that teaching literature in Literary Appreciation course requires students to read literary texts and to respond not only to the text but also a variety of visual symbols such as tableau, pictures, and sociogram. Some students from several universities in Palembang who had studied literature courses were interviewed and it could be identified that teachers asked students to examine literary works by using structuralism. The approach only sharpened intelligence.

Based on the results of the first year of research, it can be drawn that the pattern of implementation of the student literary appreciation learning at English education always be improved and revised through previous research done. The pattern of learning was collaborating two different theories that are the reader response strategy and visual symbol responses in fundamental research. It is still used in appreciating literature to develop a culture of literacy of students in speaking, listening, writing, reading and using technology. In addition, the development of learning pattern is always carried out in line with the needs and the availability of appropriate technology and fun to learn and to cultivate literacy in life through the appreciation of literature. The collaboration of the two different responses in this study is to facilitate students to develop intelligence, emotional, and behavior. Both develop a literacy of students in speaking, listening, reading, writing, 
creative writing, speaking, performance, and comment on each other, both online and offline in social network Facebook or directly in the classroom.

Based on the background of the problem, the focus of this study is how to apply the learning pattern of reader response and visual symbol responses- based literary appreciation through the social network Facebook.

\section{A. Reader Response Strategy: A New Paradigm in Literary Appreciation}

States that the reader response strategies emerged as a reaction against the New Criticism approach which focused on structuralism-oriented text. This strategy arises because of dissatisfaction of people in appreciating literary works by applying the structuralist approach. The popularity of reader response strategies by [7] is "a result of a revaluation and reclaiming of sorts." In the 70 s and 80 s, the theory of reading literary works naturally attracted academicians because the response focuses on the role of the reader and the reading process. Nevertheless, the existence of this approach is still needed in the reader response strategies as part of the response to the reader who is included in describing strategy as part of the reader response strategies.

According to [8], reader response strategies consist of seven strategies, namely:

- Engaging: Readers are always trying to engage his feelings to literature they read. Readers immerse themselves in text, imagine what will happen and feel what is felt by the characters.

- Describing: Readers elaborate or explain the information contained in the text.

- Conceiving: Readers begin to understand the characters, setting, and the language used in a story and interpret it.

- Explaining: Readers try to explain why the characters perform an action.

- Connecting: Students relate their experiences to the experience of the characters, the story compared to other stories from books or movies they watch on TV or experience of his or her own friends.

- Interpreting: Students use the reaction, conception, and connections they form to articulate themes.

- Judging: Students issue his opinion on the text of the story, the author of the story or plot.

Reader response strategy represents a new paradigm in the study of literature. This strategy shifts the old paradigm; nevertheless, the structuralist approach is still used in the reader response strategy.

\section{B. Visual Symbol Response: Bridges Redefining Literary Text}

Literary works are in words; therefore, the required response is a verbal response (spoken and written). The teaching of literature does not really produce good results. The majority of students does not love and appreciate literature. The purpose of teaching literature impossible can be achieved when teachers restrict students' response to literature. Although the teachers prefer the verbal responses, they should provide opportunities for students to respond as desired. The teachers must be able to identify the shape of the desired response. In addition, they should be aware that not all students are able to speak orally and in writing. They should support students who have the means or the other forms of responding literary works.

Presenting literature properly for teachers in English language teaching is still a big question. Many teachers refused to teach literature; they are not able to present the lesson. This happens because their reading interests (especially literature) _are very low. It is unreasonable to have students like reading literature, while teachers themselves avoid this activity. If it must be taught, they do whatever they can without trying to learn methods of literature teaching.

The use nonprinting media (visual) is an effort to expand the interpretation of student responses and knowledge gained from literature. This is in line with what is suggested by Cole and Keysser in [1] as follows, "Represents the media nonprint using an effort to extend and enrich Interpretations and responses to the literature our students read, ..." visual symbol as nonprinting media can be utilized by learners to express an aesthetic response and response to literary works in terms of shape, quality, and content. Furthermore, Purves, et.al underline the argument of Michael Cole and Helen Keysser that visual symbols as "media, too, is equipment for living" as agreed by Kenneth Burke that "literature is equipment for living."

Ref [1] list the four-dimensional visuals that can be used to respond to literary works, namely: (1) a graph consisting of sociogram, a map of the story, charts and graphs, diagrams, cartoons, and calligraphy, (2) illustration consisting of posters, photographs, and collation, (3) film/video includes animation, films, special effects, and the text of a story, and (4) performing arts consisting of mime, dance, music, and tableau.

\section{Facebook as Media of Learning in the 21st Century}

Facebook is a social networking site of the most famous in the world in this globalization era. The site facilitates everyone to connect and share with family and friends instantly via the internet. State that Facebook provides an instructor and a structure in which the learners can help each other and support one another by creating their program as a community that has been set by the students themselves. The site offers several options for students to come together into groups for discussion, collaboration, and presentation. Facebook can make learning easier because these sites are very spacious and students can connect with others with ease. Facebook is a vital tool for teaching and learning in the 21 st century and to make education more social nuance.

Furthermore, teachers and learners take a lot of benefits of Facebook, they can be connected to each other, having instant messages, comments, upload videos, upload assignments and so on. Facebook is equipped with bulletin boards, instant messaging, electronic mail and the ability to send video and pictures. Anyone can share information and collaborate within the system. On several recent occasions, Facebook has opened the download application development, which can further complete the educational function of Facebook. 
Facebook in this study as a social media that was used in teaching and learning process. Facebook as one of the largest sites used as social media in Indonesia and most of the users are students. This phenomenon is based on the results of the questionnaire distributed by [6] to the students, the data show that $97 \%$ of students agree that Facebook is important and useful not only to communicate but also to develop the ability to write.

Teachers can use Facebook to facilitate interactions between the teacher-to-student and student-student communication, share and respond to questions and needs, receive announcements, updating and managing of class collaboration [9]. They assume that the ability to communicate in English with students increases when they interact through Facebook. One feature on Facebook is the Group. Facebook groups are related to teaching media. Facebook groups are provided to give students a space in which they are under the control of the content and direction of their learning.

The students will be surfing on Facebook exchanging comments on the tableau created by their friends that have been uploaded to the Facebook group. Ref. [10] highlight three features in exploring facebook which involves students in discussions allow students to easily post and view video clips and pictures and bring the learning environment to the students' social space. This can help students express themselves better by sharing with their colleagues and allow them to do the assignment in their familiar space [10].

Currently, literacy cannot be separated from technology. Social networking sites quickly become online. According to [11] the most popular of these sites Myspace, Bebo, and Facebook. Social networking site is "service for individuals to (1) build a profile of public or semi-public in constrained systems, (2) articulate a list of other users with whom they share, and (3) view and traverse a list of their connection made by others in the system" [12]. Moreover, they also claim that social networking sites can help facilitate to meet strangers, however, people also use social networking sites to maintain and/or strengthen their social network off the line at this time.

Facebook also improve both teacher-student and studentstudent interaction in the form of web-based communication. Facebook helps instructors connect with their students about assignments, upcoming events, useful links, and examples of work outside the classroom. Students can use Facebook to contact classmates about the question of class assignments or exams and collaborate on assignments and group projects in an online environment. Build relationships face-to-face teacherstudent, the social network enables students to see a quick profile instructors that contain personal information, interests, backgrounds, and "friends," which can increase student motivation, attitude learning, and classroom climate [13].

In short, the use of social networking is really important at this time. Facebook is one medium that can be used in teaching literature. When students posted their literary works in the Facebook group, the other can provide comments and suggestions. This means that students recognize and correct their mistakes.

\section{Cultural Model for Literacy in Literature Appreciation Course}

Literary Appreciation in English language classroom has two credits. From 2006 until now, literary appreciation learning always is presented in dynamic activities. Students explore short stories and respond the stories by using visual symbols such as posters on a bulletin board in terms of writing and reader response strategy (RRS) developed from ref. [8]. Utilization of ICT is also emphasized by lecturers. Through this research, cultural literacy of students will be portrayed and analyzed in detail.

According to [6], In most societies today, literacy is part and parcel of everyday life for children and adults, and life is full of different sorts of written texts: in the home, on the street, on television, and on the computer. Literacy skills are then, not just an additional set of skills learned in schools, but an integral part of people's lives.

This statement implies some important aspects of human life in relation to literacy activities, as proposed by [14], "Literacy is reading, writing, speaking and listening and involves the knowledge and skills required to engage in activities required for effective functioning in the community." It is person's ability to speak in terms of developing writing and reading at the same time and are very closely related.

This study combines literary appreciation learning with the use of Facebook to achieve literacy-based learning as a whole. Students begin to read literature, write an appreciation of literature by using a model of literary appreciation, listen to opinions of other students about the result of appreciation, using technology both online and in the classroom. This is followed by making creative activities using visual symbols, discussing the results of student creativity and reviewing or commenting on the appreciation works of other students. This is relevant to ref [6] who puts forward: Literacy activities draw on learners' creativity and imagination allowing them to express ideas, and their relationships with their communities, in genres that are not restricted by more formal text types of reading and writing. Visual literacy is developed through activities such as viewing and discussing pictures, illustrations, photos, TV programs and movies. These activities also provide a bridge from talking to reading and writing tasks as the verbal analysis of concrete objects such as photos both aids memory and provide a focus for such tasks.

Ref. [15] The ability to use technology in a way shown by students to upload and search for novel reading material set in a variety of disciplines to be appreciated. In addition to uploading the result of the appreciation by using reader responses, students also upload a response or appreciation that uses visual symbols in the form of pictures and sociogram and upload the results of their tableau creativity after discussion.

\section{METHODS}

The method used in this research is a descriptive qualitative method. Descriptive research used because the data is arranged in the form of words or images and all things in the form of a system of signs that should not be underestimated, so it will give people something more understanding comprehension. The descriptive method can also be interpreted as a 
troubleshooting procedure investigated by depicting or describing the state of the subject or object of research at the present time based on the facts that appear or as their.

The basic assumption of the use of this method is that researchers can freely identify, understand, and map literacy learning pattern that eventually arranged into a cultural model for literacy. The aim is to elaborate, describe, map-related variables in a systematic, factual and accurate, the relationship between the phenomenon under study.

Furthermore, the data gathered partially by other student researchers under the guidance of researcher team through the application of CML for learning to speak, listening, reading and literary appreciation learning itself. Tests were carried out by the student \#1 to identify a significant difference in the group of students who were attending Speaking II course by applying CML and student \#2 to identify a significant difference in the group of junior high school students who were taking Listening course using the same model, student \# 3 to apply the model to read. Meanwhile, two students (\# 4 and \# 5) did other research on reading by using CML but does not involve the use of technology.

Other data collection method was through a questionnaire to identify correlations that may exist among the variables under investigation by the student \# 6. Data were taken with the perception questionnaire on the use of CML and documentation of student achievement Literary Appreciation of the fifth-semester students of English Education Study Program of FKIP Siriwijaya University.

Documentation of the social networking site Facebook is used by students \# 1, \# 3, and \# 6 .

The third method of data collection was done to elaborate literary appreciation learning patterns and responses based on reader response strategy and visual symbol responses by utilizing social network Facebook.

\section{RESULT AND DISCUSSION}

Collaboration between reader response strategies and visual symbol responses results in Cultural Model for Literature (CML) which is applied to the following different language skills.

\section{A. Implementation of CML in English Speaking Class}

The test was conducted by student \#1 [16] to identify a significant difference in a group of students who were attending Speaking II course. The Implementation of learning using this model with the permission and also was observed by Speaking II lecturer.

The experimental group learned to speak using CML and used literary works in the form of legends to help students speak spontaneously and accurately. At the first meeting, the pretest was given before the experiment was conducted by asking students to talk about the legend. The experimental group was taught to talk intensively for 16 meetings to know the achievement of oral language skills. This teaching took place in two months in which the experimental group was taught three times a week. The students had been taught by applying CML in their speaking class. At the end of the meeting, the students were given a final test to find out the progress and significant difference of students taught using CML with the media of legend with students using the direct method undertaken by the lecturer.

In conducting the research, ref. [16] applied the teaching procedure for the experimental group as follows.

1) Pre-Activity

Lecturer:

a) Started the lesson

b) Brainstormed by giving some questions related to the subject matter

\section{2) Core Activities}

Lecturer: students

a) Introduced the Cultural Model for Literacy to the the video

b) Showed students one example of CML activities in

c) Created a Facebook group as a medium and ask students to join

d) Divided the students into two large groups

e) Asked students to choose legends for group discussions

f) Divided again into several - small groups

g) Asked students to understand the legend and the content of the reader response strategy

h) Asked students in small groups to discuss the storyline in their legends

i) Instructed students to develop themes from their legends as most will be done in the form of a tableau while others will make a guess on it

j) Asked students to give their oral interpretation of the legend or describe what they saw from the tableau presented.

k) Asked students to integrate talking about titles or descriptions into presentations from their table. They can talk together, or assign a person to talk, or share whatever way they want.

l) Recorded the activities of student table and ask students to upload them to Facebook group

m)Asked students to comment on guessing and oral interpretations of their friends'

n) Began a discussion of group interpretation and their style of talking together with other students

o) Provided comments and values on all student activities

\section{3) Post Activities}

Lecturer: the lesson

a) Allowed students to provide some questions related to

b) Concluded what has been learned with the students

c) Ended the lesson 
Based on the results of the study, ref. [16] concluded the following. Prior to giving treatment, the authors gave pre-tests to students of both experimental and control groups. When CML with the legend was introduced, students were highly motivated in learning to speak. Students who were reluctant to speak at the beginning of the treatment, in the end, most of them enjoyed and felt easy to talk. The application of CML as a whole became media and a good approach for teachers to teach English and they could vary the way their teaching and learning activities.

The students who were taught by applying CML with the legend in their speaking class had a better score in providing interpretations of the legend than those in the control class. Appreciating oral legend was a practice activity in teaching English especially speaking. They seemed to be more active in conveying their ideas, thinking to guess and having good knowledge in responding to literary works. Using independent t-test, Sari analyzed the difference between the post-test results in the control group and the experimental group. The $-t$ value found is 3.252. At the significant p level $<0.005$ for the tail test with $\mathrm{df}=39$, the critical value t-table is 2.023 . Since the $\mathrm{t}$ values are higher than the t-table, the null hypothesis (H0) is rejected and the research hypothesis (H1) is accepted. From the calculations, it was found that there was a significant difference in posttest scores of students in the experimental group and the students in the control group. This can prove that the CML in the speaking class is able to improve students' speaking ability. The application of MBL in teaching to speak with the legend can attract students to learn English especially speaking. During the treatment, Sari observed that the students were actively involved in the teaching and learning process. This situation occurred because she taught to speak in a different way than the lecturers did. By applying this model, she did not only build the willingness of students in English but also gave them fun in teaching and learning activities. Finally, CML with legend could be used as one of the models in improving students' speaking ability.

\section{B. The Implementation of CML in Learning Listening at Junior High School}

Student \#2 [17] identified a significant difference in a group of junior high school students who were taking a Listening lesson by using the same model. In this case, Fattah did not use MBL as a whole because the sample of his research is high school students.

In this study, preliminary tests were administered to both experiment and control. The experimental group was treated by using a digital short story on Facebook. Meanwhile, the control group was not given any treatment. They were taught by their teacher. After doing the experiment, Fattah also gave the final test the same as the initial test. In the experimental group, students use short stories on Facebook. During the treatment, the experimental group was taught with an allocation of time of 80 minutes ( $2 \times 40$ minutes) per meeting. Teaching and learning materials were taken from Youtube. The teaching and learning process was conducted for 16 meetings. The following are the steps that [17] adapted from the literary culture model developed by [18]
Pre-activities:

1) The teacher greeted the students at the opening of the class.

2) Teachers motivated students by asking them some related questions.

3) The teacher told the purpose of the study.

Core activities:

1) The teacher explained what digital short story.

2) The teacher explained how to listen to short stories carefully.

3) The teacher asked the students to log in their Facebook account while the teacher is explaining and writing lessons.

4) The teacher asked the students to find the main idea of the story.

5) The teacher told the student the character type.

6) The teacher asked the students to find the main character of the story.

7) The teacher guided the students and informed the mistakes made by them.

End activities:

1) The teacher gave students time to ask about what they do not understand but from today's lesson.

2) Teachers and students summarized lessons together.

3) The teacher closed the activity.

In this ref. [17] study, digital short stories can improve students' listening comprehension. Most of them also agree or strongly agree that the incorporation of short stories in language skills classes will help learners achieve better mastery of language skills. This can be interpreted that after the treatment, there was an improvement in students' listening achievement.This means that teaching listening comprehension through digital short stories helped students improve their listening comprehension.

Based on research results, digital short stories could make students interested in learning to listen. Most students were active. It was because digital short stories are the latest learning activity they have done and it was fun for them. Digital short stories could be used as one of the methods in teaching listening at junior high school.

\section{Application of CML in Writing}

The Literacy Culture Model could motivate students to write. This is done in Literary Appreciation course of English students at semester V academic year 2014/2015 consisting of two classes, Indralaya class as many as 40 students and Palembang class as many as 27 students. Student writing activities always are begun with reading activities. In this case, the researcher asked the students of the Indralaya campus to read the Legend of Kemaro Island, a legend originating from Palembang, The Bucket Rider short story written by Frank Kafka, writing a song interpretation, writing their responses to Indonesian folklore, and writing short stories based on 
experience or fiction with the focus of one of human character. Meanwhile, Palembang college students are doing the same thing but there are different sources of reading, that is, they read and write their response to a short story written by Leo Tolstoy entitled God Sees the Truth, But Waits.

Here are some examples of writing done by students in groups on Facebook that is LITERARY APPRECIATION group 2014 WITH RI INDERALAYA in the site https://www.facebook.com/groups/760456407329106/.

\section{1) Writing Song Interpretation}

Bilal Bani Al'Amin (06121001032) song interpretation "Hero from Mariah Carey". This song tells us that everyone can be a hero. Although we are the worse people in this world, if we believe in ourself and follow the path to reach our dream until we get it, we will be a hero for someone and for ourself. The obstacles while reaching the dream will make us be a better person. Because the obstacles itself are the best teacher which can guide us to a better life.

Hafsah Rizqiyah (06121001001) interpretation of Hero by Mariah Carey. The song with the title "Hero" motivates me to be a brave person and not to give up easily. Every single person in this world has the bravery in herself/himself, but how biggest that bravery is depended on that individual. Everybody has their own ways to solve the problems, just focus on those, and try to find the answer from your heart and mind. The problem exists just because it must be solved, and of course, there is a solution. You are the hero for yourself; belief in your ability and strength. God will help for those who never give up trying and praying to Him. The problems come to make the person stronger to continue the life and struggle of surviving. Therefore, you must be independent, do not let yourself depend on others. All your dreams will come true, and never stop to dream and make your dreams come true with the efforts and prayers. Life is the long road, so that is why you must be strong; always carry your hope because the hero is always in you.

\section{2) Writing on Literary Appreciation}

Salama (06121001042) The Bucket Rider. The bucket rider is a story written by Kafka, this is a gloomy story which the antagonist is the bucket rider and the protagonist is the wife of coal dealer. The bucket rider is an old man who wants to debt a little coal to warm himself in that winter but he got nothing except degradation because of the wickedness of the coal dealer's wife. the antagonist one is a terrible character here, she is coal dealer's wife. she is a wicked woman, arrogant, and a liar. This story took place in the snowy street, in front of the coal dealer's store. This is a good background because of it tells the gloominess of the situation at that time. The most important event in this story is when the old man decided to buy the coal in the coal dealer, then the sad tragedy happened. Which is the coal dealer's wife humiliate the old man and lie to her husband who is deaf. The situation at that time is cold and quiet, the old man had used up all his coal and he decided to buy a little coal to keep himself warm. He decided to buy the coal to that coal dealer because of he was an old customer. The bucket rider is freezing. He is hoping the coal dealer to give him the coal in debt, but the coal dealer's wife won't give him and chased him away. If I were the protagonist one, I will do the same to survive at first but if I can't get the coal I'll go to another coal store. A protagonist is an honest person. Even though he knew that maybe the coal dealer won't give his the coal because of he wants to buy the coal in debt, he still honest and not tell a lie to the coal dealer that he has no money and I as a reader really appreciate the honesty of the bucket rider. The important word in this story is the "coal" this is the problem of this story. The coal itself is the object problem of this story. I myself have an experience that almost similar to this story, when I beg something to other people but that people humiliate me and that is hurt so much. There are so many novels and film that has similar scenes with this story, that tell about the wickedness of someone to another. Thi story want to tell us about how to interact with other, it shows as a human being we must help each other and if we compare this story with the culture of Indonesia then it doesn't match. The culture of Indonesia suggests us to care each other as Indonesian. And also it doesn't match with my religion which is Islam which also suggests caring each other as Muslims. The protagonist in this story has a work hard characteristic. It shows when she walk in cold to get the coal in the coal store. Overall, this story is really interesting and also useful. The biggest lesson that we could get from this story is to care each other. The writer of this story is really creative, he could bring the reader into the gloominess of the story through its words. Perfect!

Based on the writing activities conducted in a Facebook group, it can be concluded that Facebook itself as a medium of communication both oral and written is very useful for students to express their thoughts and feelings both academically and imaginatively.

\section{Application of CML in Literary Appreciation}

Other data collection methods are through questionnaires to identify possible correlations among the variables investigated by student \#6 [19]. Application of CML in Literature Appreciation course could influence the achievement of good literary appreciation. Eighteen students (28\%) scored very well and 47 students $(72 \%)$ rated well. No student was judged enough, low, and failed. The sociogram can make students enjoy writing short stories because the sociogram provides some information in helping students write short stories and the sociogram can increase their interest in learning to write short stories. In addition, the use of seven reader responses in literary reading is very useful to them.

The results of [19] in questionnaire showed that students gave positive perceptions and good responses regarding the use of CML in the Literary Appreciation lecture of $84.99 \%$. CML consists of reader response strategies that were agreed by $76.12 \%$, visual symbols include sociogram $(85.90 \%)$, images $(88.03 \%)$, and table $(85.90 \%)$, and peer comments on Facebook for $88.90 \%$. Revealed that the reader response approach aims to enable learners to develop their response to literature and to enhance their critical attitudes toward literary texts.

Meanwhile, the sociogram helps students to appreciate the literary works, to understand the story, and to remind all the characters in the story. Sociogram also makes it easier for students to explore the relationship between story characters. Teachers can create literary sociograms, graphic organizers 
representing relationships between characters in literary texts. In addition, the construction of a sociogram to be the most valuable literary teaching technique because of adaptation.

The picture itself is used to convey meaning and open new ideas for interpretation. Involving students in a picture book, or other text that included new words and new concepts could be language proficiency. It is easy for students to retell the story by looking at the picture. Unlike the picture, a table as 'still picture' has many benefits in learning literature. Tableau can be a useful tool for language and literature teachers. This encouraged students to slow down and think about the meaning of important events in the text, as well as taking into account the different viewpoints of characters. The last part of CML was a peer comment on Facebook. According to them, Facebook can be useful to communicate. Students do not make the same mistake after reading the comments of their friends. They can also express their ideas freely within Facebook groups.

Correlation research results of [19] showed that there is a relationship between perceptions about the use of CML and achievement student literary appreciation. It was also positively correlated which means that the two variables were heading in the same direction. When lecturers applied CML in lectures, their Literary Appreciation achievement was good. In addition, the relationship between CML usage and student's literacy achievement is significant since r-value was higher than r-table. This means that the students' literary appreciation achievement was influenced by their perception about the use of CML.

\section{CONCLUSION}

Collaboration between the reader response strategy and visual symbol generated Cultural Literacy Model which was applied to the four language skills integrated into a single procedure at the college level in this case language education and could also focus on one language activity at the school level. CML by using tableau of legends could improve the ability to speak. To improve listening skills, digital stories uploaded to the Facebook group. Meanwhile, narrative text and reader response strategies to improve reading comprehension, as well as narrative text and sociogram can facilitate students understand the relationships between characters.

\section{ACKNOWLEDGMENT}

Thanks for the fund given through Hibah Fundamental by Direktorat Jenderal Pendidikan Tinggi, Kementerian Pendidikan dan Kebudayaan, dengan Surat Perjanjian Nomor:1108.a/UN9.4.2/LK-ULP/2013

\section{REFERENCES}

[1] Purves, A.C., Roger, \& Soter. (1990). How Porcupines Make Love II: Teaching a Response-Centered Literature Curriculum. New York: Longman Group, Ltd.

[2] Cross, H. (2011). Visual symbols. [Web Log Post]. Retrieved on February 28, 2013, from http://hcdceductech.blogspot.com/2011/09/visual-symbols.html

[3] Smith, D. (2004). Practical classroom strategies that work: Using sociograms as a behaviour management tool. Brunei Darussalam: Universiti Brunei Darussalam, Bandar Seri Begawan. Retrieved on February 3, 2013, from http://www.aase.edu.au/phocadownload/Papers_from_past_National_Co
nferences_pre_2009/2004\%20nat\%20conf\%20Practical\%20classroom $\%$ 20strategies\%20that\%20work\%20-\%20D0016.pdf

[4] Inderawati, R. (2005). "Keefektifan Model Respons Pembaca dan Simbol Visual dalam Pembelajaran Sastra di SD." Makalah. Dipresentasikan dalam Konferensi Internasional Himpunan SarjanaKesusasteraan Indonesia (HISKI) XVI di Palembang, 18-21 Agustus 2005 .

[5] Inderawati, R. (2007). Model Pembelajaran Berbasis Respons Pembaca dan Simbol Visual sebagai Upaya Inovatif Mengembangkan Apresiasi Sastra dan Kemampuan Berbahasa Inggris Mahasiswa. Laporan Akhir Penelitian Hibah Bersaing Tahun I.JPBS FKIP Universitas Sriwjaya Palembang.

[6] Inderawati, R. (2011). From Classroom to Peer Comment in Facebook: Bridging to Establish Learners' Literacy. Dipresentasikan dalam The 4th International Conference ICT for Language Learning di Florence, Italy, 20-21 Oktober 2011

[7] Huang, W., Hong, S. H., Eades, P. (2007). Effects of sociogram drawing conventions and edge crossings in social network visualization. Journa of algorithms and application 11(2), 397-429. Retrieved on April 18, 2012.

[8] Beach, R.W. \& Marshall, J.D. (1991). Teaching Literature in the Secondary School. New York: Harcourt Brace Jovanovich, Inc.

[9] Mahmud, M.M., \& Ching, W.C. (2012). Facebook does it really work for L2 learners. Savap International Journal, 3(2). Retrieved from http://www.savap.org.pk/journals/ARInt./Vol.3\%282\%29/2012\%283.247\%29.pdf

[10] Mobrand, E. (2011). Facebook for teaching and learning. Technology in pedagogy. Retrieved from http://www.cdtl.nus.edu.sg/technology-inpedagogy/articles/Technology-in-Pedagogy-1.pdf

[11] Stelter, B. (2008). AOL buying No. 3 social networking site. Retrieved from http://www.nytimes.com/2008/03/14/technology/14aol.html.

[12] Boyd, D. M., \& Ellison, N. B. (2008). Social network sites: Definition, history, and scholarship. Journal of Computer-Mediated Communication, 13, 210-230.

[13] Hill, S. (2008). Developing Early Literacy Assessment and Teaching. Praharan: Eleanor Curtain Publishing.

[14] Mazer, J. P., Murphy, R.E., \& Simonds, C. J. (2007). I'll see you on 'Facebook': The effects of computer-mediated teacher self-disclosure on student motivation, affective learning, and classroom climate. Communication Education, 56, 1-17.

[15] Inderawati, R., Sofendi, \& Zuraida. (2013a). Penerapan Strategi Respons Pembaca dan Respons Simbol Visual dalam matakuliah Literary Appreciation untuk mengembangkan Budaya Literasi. Makalah dalam Prosiding Literature and Nation Character Building dipaparkan dalam The 23rd HISKI Conference on Literature Lambung Mangkurat University, Banjarmasin, November 6-9, 2013

[16] Sari, F.S.P. (2014) The Application of Cultural Model for Literacy through Legends to Enhance Speaking Ability of the Second Semester of English students of Sriwijaya University. Unpublished Thesis of FKIP Unsri.

[17] Fattah, M.A. (2014). The Use of Digital Short Stories in Facebook to Enhance Listening Comprehension of the Eighth Graders of SMP Nigeria 9 Palembang. Unpublished thesis. FKIP Unsri.

[18] Inderawati, R., Sofendi, \& Zuraida. (2013b). Strategi Respons Pembaca dan Respons Simbol Visual dalam matakuliah Literary Appreciation untuk pengembangan Budaya Literasi Mahasiswa Pendidikan Bahasa Inggris FKIP Universitas Sriwijaya. Laporan Penelitian Fundamental Disentralisasi, Dibiayai oleh Direktorat Jenderal Pendidikan Tinggi, Kementerian Pendidikan dan Kebudayaan, dengan Surat Perjanjian Nomor:1108.a/UN9.4.2/LK-ULP/2013.

[19] Septiana, E. (2014). The correlation between the perception on the use of cultural model for literacy and literary appreciation achievement of the 5th-semester students of English Education study program of FKIP Sriwijaya University. Unpublished Thesis of FKIP Unsri. 